\title{
CD4-Pseudomonas Exotoxin Conjugates Delay but Do Not Fully Inhibit Human Immunodeficiency Virus Replication in Lymphocytes In Vitro
}

\author{
Hiroshi Tsubota, ${ }^{\star}$ Gunther Winkler, ${ }^{\ddagger}$ Harry M. Meade, ${ }^{\ddagger}$ Aniela Jakubowski, ${ }^{\ddagger}$ David W. Thomas, ${ }^{\ddagger}$ and Norman L. Letvin ${ }^{\star}$ \\ ${ }^{*}$ Harvard Medical School, New England Regional Primate Research Center, Southborough, Massachusetts 01772; and \\ ${ }^{\ddagger}$ Biogen, Incorporated, Cambridge, Massachusetts 02142
}

\begin{abstract}
The CD4 molecule is a high affinity receptor for the human immunodeficiency virus (HIV) envelope glycoprotein (gp160 or gp120). This glycoprotein is expressed on the surface membrane of cells infected with HIV. It has, therefore, been suggested that a soluble form of CD4 might be used as a targeting agent to deliver toxins selectively to cells infected with HIV. We demonstrate that CD4-Pseudomonas exotoxin A (PE) conjugates inhibit the proliferation of gp160-transfected Chinese hamster ovary cells and block HIV replication in virusinfected $\mathrm{H} 9$ cells. However, this inhibition of HIV replication appears to be incomplete since virus replication occurs following removal of the toxin conjugates from these cultures. Moreover, CD4-PE conjugates delay but do not inhibit HIV replication in human peripheral blood lymphocytes. These studies suggest that such conjugates should be assessed only as potential adjunctive therapies in the acquired immunodeficiency syndrome. (J. Clin. Invest. 1990. 86:1684-1689.) Key words: acquired immunodeficiency syndrome therapy $\bullet$ antiviral drug • HIV • Pseudomonas exotoxin conjugates
\end{abstract}

\section{Introduction}

The CD4 molecule is a high affinity receptor for the human immunodeficiency virus (HIV) envelope glycoprotein (1). Anti-CD4 monoclonal antibodies block HIV infection of target cells in vitro $(2,3)$. Cells not expressing the CD4 molecule may become susceptible to HIV infection following transfection with the CD4 gene (4). Moreover, it has recently been shown that a soluble form of the extracellular portion of the CD4 molecule created through recombinant DNA technology can block HIV infection of cells in vitro (5-9).

It has been suggested that a soluble form of CD4 may prove valuable in the therapy of HIV-infected individuals by directly competing with cell surface expressed CD4 molecules for the binding of virus. In fact, recent studies in simian immunodeficiency virus-infected rhesus monkeys and HIV-infected humans suggest that this approach may be of therapeutic value (10-12). It has also been proposed that soluble CD4 might be employed for the targeting of toxins to cells infected with HIV. Thus, cells infected with HIV and expressing virus envelope glycoprotein on their surface might specifically bind a CD4

Address reprint requests to Dr. Norman Letvin, Harvard Medical School, New England Regional Primate Research Center, One Pine Hill Drive, Southborough, MA 01772.

Received for publication 25 January 1990 and in revised form 4 June 1990

J. Clin. Invest.

(C) The American Society for Clinical Investigation, Inc

0021-9738/90/11/1684/06 \$2.00

Volume 86, November 1990, 1684-1689 toxin conjugate and be killed as a result of that interaction. In vitro experiments have indicated that this approach may be feasible (13-16).

We have recently initiated studies to explore the possible use of CD4-toxin conjugates in the treatment of AIDS. In these experiments, we demonstrate that CD4-Pseudomonas exotoxin (PE) ${ }^{1}$ conjugates can inhibit HIV replication in cell populations in vitro. However, this inhibition of virus replication appears to be incomplete.

\section{Methods}

Materials. Murine anti-CD4 (19Thy5D7) and anti-CD8 (7PT3F9) monoclonal antibodies (MAbs) were provided by Dr. S. F. Schlossman (Dana Farber Cancer Institute, Boston, MA). Mitomycin-C was purchased from Sigma Chemical Co. (St. Louis, MO). Recombinant human IL-2 was provided by Hoffman-LaRoche (Nutley, NJ). The Chinese hamster ovary (CHO) cell lines expressing HIV gp160/120 and mullerian inhibiting substance were gifts of Dr. M. Rosa (Biogen, Inc., Cambridge, MA).

CD4-toxin proteins. The CD4-PE constructs used in these studies were expressed by Escherichia coli renatured and purified by immune-affinity chromatography using an anti-CD4 monoclonal antibody bound to $\mathrm{BrCN}$-activated Sepharose as described by Winkler et al. (manuscript in preparation) (Fig. 1). Both contained amino acids 1-181 of the human CD4 molecule, its two amino-terminal Ig-like domains $(16 \mathrm{a}, 16 \mathrm{~b})$. The shorter construct, CD4-PE(364), contained amino acids $250-613$ of PE, its 364 carboxy-terminal amino acids (16c). This consists of domains II (the portion required for translocation of the toxin into the cytoplasm of a target cell), Ib, and III (the portion responsible for ADP-ribosylation of elongation factor 2) (16d). The longer construct, CD4-PE(392), contained, in addition, the carboxy-terminal 28 amino acids of domain I which are involved in cell recognition (16d).

Cell proliferation experiments. $\mathrm{CHO}$ cells transfected with genes encoding HIV envelope glycoprotein gp160 or mullerian inhibiting substance were plated in 96-well plates at a density of $2 \times 10^{4}$ cells/well in MEM alpha medium (without ribonucleotides and deoxyribonucleotides) (Gibco Laboratories, Grand Island, NY) supplemented with $10 \%$ dialyzed fetal bovine serum (Gibco) and $4 \mathrm{mM}$ L-glutamine. After an overnight incubation, medium was removed and replaced by fresh medium containing CD4-PE. For blocking experiments, $0.5 \mu \mathrm{M}$ recombinant soluble CD4 was also added. After $24 \mathrm{~h}$ incubation, 1 $\mu \mathrm{Ci} /$ well $\left[{ }^{3} \mathrm{H}\right]$ thymidine (New England Nuclear, Boston, MA) was added and incubation was continued for another $24 \mathrm{~h}$. Cells were harvested and lysed on a PHD cell harvester (Cambridge Technology, Inc., Cambridge, MA) and incorporated radioactivity was determined by scintillation counting.

Virus. H9 cells infected with HIV-1 (HTLV-III B strain) were used as a source of virus. The cell line was maintained in RPMI 1640 medium (Gibco Laboratories) supplemented with 10\% FCS (Flow Laboratories, Inc., McLean, VA), L-glutamine ( $2 \mathrm{mM}$ ), penicillin (50 $\mathrm{U} / \mathrm{ml})$, and gentamycin $(50 \mu \mathrm{g} / \mathrm{ml})$.

1. Abbreviations used in this paper: $\mathrm{CHO}$, Chinese hamster ovary; MMC, mitomycin C; PE, Pseudomonas exotoxin A; RT, reverse transcriptase. 
CD4(181)-PE(364)

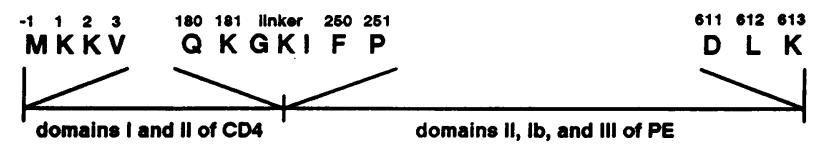

\section{CD4(181)-PE(392)}

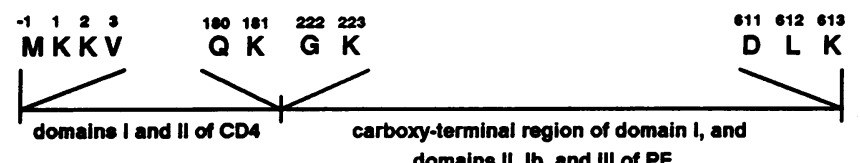

domains II, lb, and III of PE

Figure 1. Structure of CD4-PE recombinant proteins utilized in these studies. Both hybrid toxins used in these experiments contained amino acids 1-181 of the human CD4 molecule, its two amino-terminal domains. The shorter of the two constructs contained residues 250-613 of PE, the 364 carboxy-terminal amino acids; the longer contained an additional 28 amino acids comprising the carboxy-terminal region of domain $I$, the cell recognition domain of PE.

Cultures of HIV-infected H9 cells with CD4-PE. $2 \times 10^{4} \mathrm{HIV}$-1-infected $\mathrm{H} 9$ cells were placed in 24-well culture plates (Gibco Laboratories). Increasing concentrations of CD4-PE and then $2 \times 10^{5}$ uninfected $\mathrm{H} 9$ cells were introduced into each well. Cells were washed after $3 \mathrm{~d}$ in culture; new medium and CD4-PE were then added to each well. CD4-PE was added to each well again on day 5 . Thereafter, medium was changed and new CD4-PE was added to each well every $2 \mathrm{~d}$. Cultures were maintained at $37^{\circ} \mathrm{C}$ in a humidified $5 \% \mathrm{CO}_{2}$ atmosphere.

Peripheral blood lymphocyte (PBL) preparation. Heparinized blood was obtained from HIV-1 seropositive or seronegative volunteers. PBLs were isolated from the heparinized blood by Ficoll-diatrizoate density gradient centrifugation. They were washed with PBS, resuspended in RPMI 1640 supplemented with $10 \%$ FCS at a concentration of $1 \times 10^{6} / \mathrm{ml}$, and activated with $10 \mu \mathrm{g} / \mathrm{ml}$ concanavalin A (Con A) for 3-4 d. CD8+ cells were depleted from these Con A-activated PBLs by the panning method $(17,18)$. PBLs were incubated at a concentration of $1.5 \times 10^{7} / \mathrm{ml}$ for 40 min at $4^{\circ} \mathrm{C}$ with anti-CD8 $\mathrm{MAb}$ (7PT3F9) in ascites form at a dilution of 1:125. The cells were then washed twice with PBS and resuspended in PBS at a concentration of 4 $\times 10^{6}$ cells $/ \mathrm{ml} .3 \mathrm{ml}$ of this cell suspension was plated on a $10-\mathrm{cm}$ plastic petri dish coated with $10 \mu \mathrm{g}$ rabbit anti-mouse Ig (Dako Corp., Santa Barbara, CA) and preincubated with $10 \mathrm{ml}$ of PBS supplemented with $2 \%$ FCS. Cells were incubated on these dishes for $70 \mathrm{~min}$ at $4^{\circ} \mathrm{C}$. The dishes were then swirled and cells in the supernatant were harvested. These cells were used as a CD8+ cell-depleted population. CD8 + cell-depleted PBLs were maintained in RPMI 1640 medium supplemented with $10 \%$ FCS and $20 \mathrm{U} / \mathrm{ml} \mathrm{IL-2}$ at a concentration of 1 $\times 10^{6}$ cells $/ \mathrm{ml}$.

Reverse transcriptase (RT) assay. RT activities of culture supernatants were measured as described (19). Briefly, $1.4 \mathrm{ml}$ of each supernatant was centrifuged in a 1.5 -ml Eppendorf tube at $12,000 \mathrm{~g}$ for $90 \mathrm{~min}$. The supernatant was removed and pelleted virus was incubated on ice for $10 \mathrm{~min}$ with $20 \mu \mathrm{l}$ of dissociation buffer $(0.01 \mathrm{M}$ Tris- $\mathrm{HCl}, \mathrm{pH}$ 7.3/0.2\% Triton X-100/0.001 M EDTA/0.05 M dithiothreitol/0.06 M $\mathrm{KCl}) .15 \mu \mathrm{l}$ of dissociated virus solution was mixed with $60 \mu \mathrm{l}$ of assay mixture (0.05 M Tris-HCl, pH 8.3/0.007 $\mathrm{M} \mathrm{MgCl}_{2} / 0.06 \mathrm{M} \mathrm{KCl} / 0.08$ $\mathrm{mg}$ of poly(rC)-oligo(dG) primer per $\mathrm{ml} / 0.007 \mathrm{M}$ dithiothreitol/3.3 $\mu \mathrm{Ci}$ of $\left.\alpha-{ }^{32} \mathrm{p}\right] \mathrm{dGTP}$ [3,000 Ci/mmol; Amersham Corp., Arlington Heights, IL]) and incubated at $37^{\circ} \mathrm{C}$ for $60 \mathrm{~min} .60 \mu \mathrm{l}$ of each sample was dropped onto a Whatman 3 disk. Each disk was washed in a beaker with $5 \%$ trichloroacetic acid/ $2 \%$ sodium pyrophosphate, rinsed, dried, and radioactivity of each disk was measured.

\section{Results}

CD4-PE inhibits replication of $\mathrm{CHO}$ cells expressing $\mathrm{HIV}$ gp160. The toxicity of a CD4-PE hybrid toxin was first assessed on $\mathrm{CHO}$ cells expressing the HIV envelope glycoprotein gp160. CHO cells transfected with either gp160 or a control gene coding for mullerian inhibiting substance were maintained in culture for $48 \mathrm{~h}$ with increasing concentrations of CD4-PE(364). $\left[{ }^{3} \mathrm{H}\right]$ thymidine incorporation by these cells was then measured as an indication of cell replication. As shown in Fig. 2, a $50 \%$ inhibition of $\left[{ }^{3} \mathrm{H}\right]$ thymidine incorporation by gp160-transfected $\mathrm{CHO}$ cells was seen at a $1.5 \times 10^{-12} \mathrm{M}$ concentration of CD4-PE. This inhibition of replication was dependent upon the gp160 interaction with CD4-PE, since it was completely eliminated by the addition of soluble CD4 at a concentration of $0.5 \mu \mathrm{M}$. No significant CD4-PE toxicity on control $\mathrm{CHO}$ cells expressing mullerian inhibiting substance protein was seen at concentrations less than $2.0 \times 10^{-9} \mathrm{M}$. Thus, a significant "window" exists between the specific toxicity of CD4-PE for gp 160-expressing CHO cells and the nonspecific toxicity of this conjugate for $\mathrm{CHO}$ cells expressing an irrelevant molecule. However, that toxicity window appeared to be smaller for $\mathrm{H} 9$ than for $\mathrm{CHO}$ cells, since 50-nM CD4-PE exhibited significant toxicity for uninfected $\mathrm{H} 9$ cells (data not shown).

CD4-PE inhibits HIV replication in vitro. The ability of two different CD4-PE constructs to block HIV replication in vitro was then assessed. Uninfected $\mathrm{H} 9$ cells, a HIV-permissive cell population, were cultured with $\mathrm{H} 9$ cells that were chronically infected with HIV. Increasing concentrations of two different CD4-PE constructs were maintained in these cultures and in vitro HIV replication was monitored by quantitating RT activity in the culture supernatants. RT activity was detected in these supernatants by day 7 of culture in the absence of CD4-toxins. However, both CD4-toxin constructs completely inhibited HIV replication when maintained in culture at a 6.0-nM concentration (Fig. 3). CD4-PE(392) appeared to block HIV replication marginally more effectively than CD4$\mathrm{PE}(364)$ at a 0.2-nM concentration. CD4-PE(392) was also marginally more efficient than CD4-PE(364) in lysing gp 160transfected CHO cells (Winkler et al., manuscript in preparation). The CD4-PE constructs were not cytotoxic for uninfected $\mathrm{H} 9$ cells at those concentrations (data not shown).

$H I V$ replication occurs after removal of CD4-PE from cultures. We then sought to determine whether the introduction of CD4-PE in vitro for a finite period of time permanently eliminated replicating HIV in these cultures. Uninfected H9

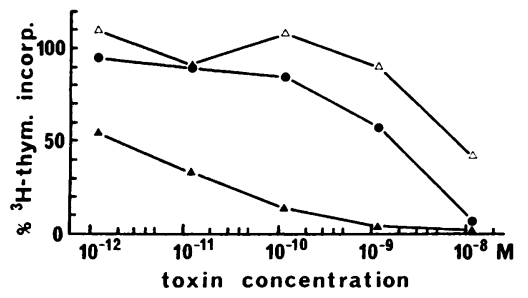

Figure 2. CD4-PE inhibits replication of CHO cells expressing the HIV gp160. gp160transfected $\mathrm{CHO}$ cells (ム) or CHO cells transfected with mullerian inhibiting substance $(\Delta)$ were cultured in the presence of CD4-PE(364) for $48 \mathrm{~h}$. Soluble CD4 at a $0.5-\mu \mathrm{M}$ concentration was also added to such a culture of CD4-PE-treated cells (๑). $\left[{ }^{3} \mathrm{H}\right]$ thymidine was added for the last $24 \mathrm{~h}$ of culture, cells were harvested, and incorporated radioactivity was determined. This was then expressed as a percentage relative to untreated cells. 


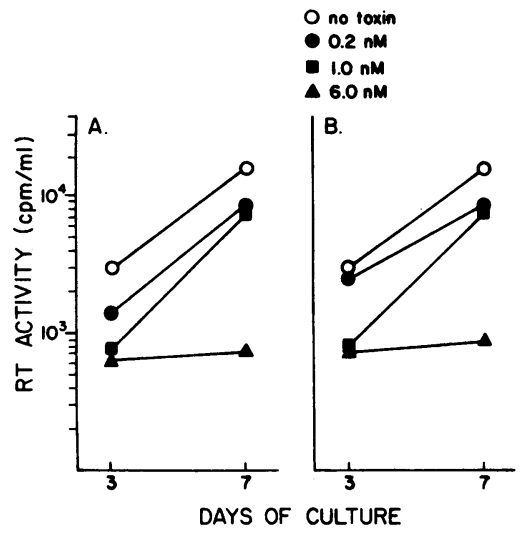

$1.0 \mathrm{nM},--6.0 \mathrm{nM}) . \mathrm{RT}$ activity in culture supernatants was measured as an indication of HIV replication. $A$ and $B$ indicate the results of studies done using CD4-PE(392) and CD4-PE(364), respectively.

cells and HIV-infected $\mathrm{H} 9$ cells were cocultivated in the presence of 12.0-nM CD4-PE(392). CD4-PE was, however, removed from the cultures on day 3 , day 7 , or day 10 . In each of these instances, HIV replication was detected immediately after CD4-PE was removed from the cultures (Fig. 4). Therefore, a 12.0-nM concentration of CD4-PE inhibited HIV replication only as long as it was present in culture. Moreover, when CD4-PE was maintained in a similar culture system for $10 \mathrm{~d}$ at a $6.0-\mathrm{nM}$ rather than $12.0-\mathrm{nM}$ concentration, a concentration that fully abrogated HIV replication for a 7-d culture period, virus replication was readily demonstrable by day 10 (Fig. 5).

CD4-PE does not block transmission of HIV from infected to uninfected $\mathrm{H} 9$ cells. Thus, CD4-PE exposure appeared to delay but did not abort the generation of RT activity in these cultures. This HIV replication could reflect the transmission in culture of HIV from virus-infected to virus-free H9 cells. It could, however, also simply represent the gradual expansion of the HIV-infected $\mathrm{H} 9$ cells originally introduced in vitro as a source of virus. To differentiate between these two possibilities, cell-associated HIV was introduced into the cultures of uninfected $\mathrm{H} 9$ cells in a cell population which could not expand and support HIV replication. We have previously found that mitomycin C (MMC)-treated HIV-infected H9 cells can

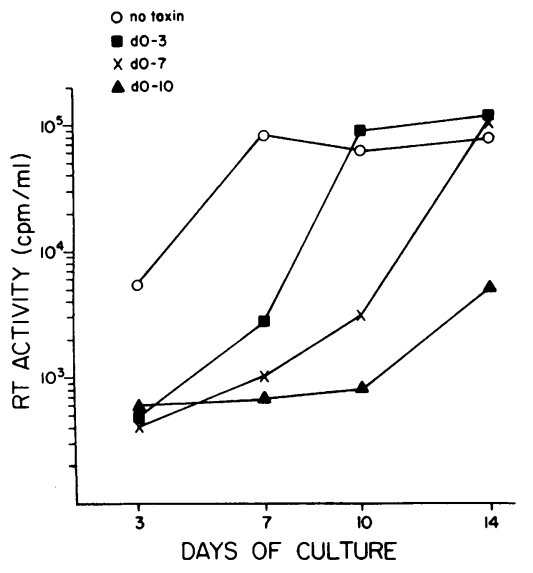

Figure 4. The inhibition of HIV replication in $\mathrm{H} 9$ cells persists only as long as 12.0-nM CD4$P E$ is present in culture. $2 \times 10^{5} \mathrm{H} 9$ cells were cocultured with $2 \times 10^{4}$ HIV-infected $\mathrm{H} 9$ cells in the continuous presence of 12-nM CD4PE(392) for the period of time indicated.

- $0-$, no toxin;

- - , day 0-3;

$-\times-$, day $0-7$;

$-\Delta-$, day $0-10$.

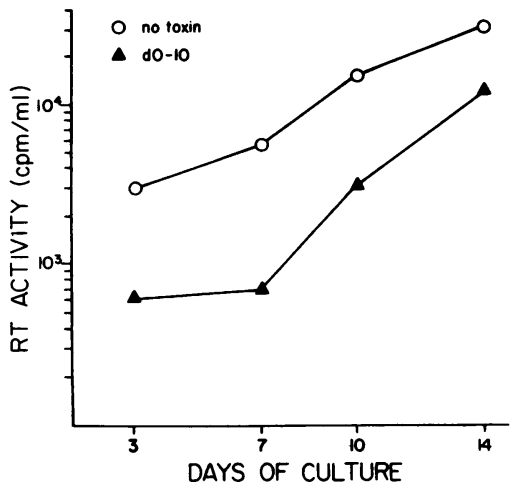

Figure 5. HIV replication in $\mathrm{H} 9$ cells is delayed but not fully abrogated in the presence of 6.0-nM CD4PE. $2 \times 10^{5} \mathrm{H} 9$ cells were cocultured with 2 $\times 10^{4}$ HIV-infected $\mathrm{H} 9$ cells in the continuous presence of 6-nM CD4$\operatorname{PE}(392)$ from day 0 to day 10 of culture. - o - , no toxin; $-\triangle-, 6 \mathrm{nM}$ CD4-PE.

serve as a source of cell-associated HIV in culture while not supporting the continued replication of this virus (data not shown). Therefore, MMC-treated, HIV-infected H9 cells were placed in culture with uninfected $\mathrm{H} 9$ cells in the presence of 6.0-nM CD4-PE. While no RT activity was detected in culture supernatants of the MMC-treated, HIV-infected H9 cells alone, RT activity was generated when uninfected H9 cells were introduced in vitro (Fig. 6). Therefore, HIV transmission from infected to uninfected $\mathrm{H} 9$ cells occurred in culture in the continuous presence of CD4-PE.

CD4-PE delays but does not block HIV infection of PBLs. We next assessed the ability of CD4-PE to block HIV infection in a more biologically relevant cell population, PBLs. Con A-activated, CD8 + cell-depleted PBLs obtained from an uninfected donor were cocultured with MMC-treated, HIV-infected $\mathrm{H} 9$ cells. CD4-PE was maintained at different concentrations in the cultures from day 0 to day 7 . Virus replication was detected as early as day 3 in the control culture, with peak RT activity noted on day 7 of culture (Fig. 7). CD4-PE delayed HIV infection of PBLs in a dose-dependent manner. CD4-PE at a $0.2-\mathrm{nM}$ concentration did not inhibit HIV replication (data not shown). The peak RT activity generated in a culture maintained in 1.0-nM CD4-PE was a bit lower than that of the control culture (data not shown). Finally, no significant increment in inhibitory activity was observed in cultures main-

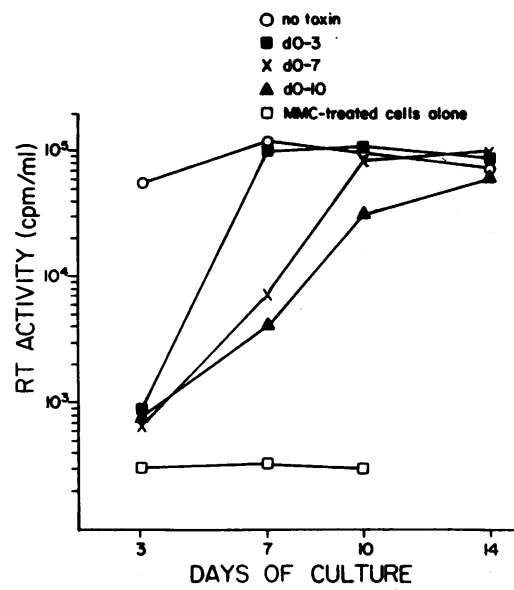

Figure 6. CD4-PE blocks transmission of infection from mitomycin C-treated HIV-infected H9 cells to uninfected $\mathrm{H} 9$ cells, albeit transiently. $2 \times 10^{5} \mathrm{H} 9$ cells were cocultured with $2 \times 10^{4}$ mitomycin C-treated, HIV-infected $\mathrm{H} 9$ cells in the presence or absence of 6-nM CD4-PE (392) for various periods of time. As a negative control, 2 $\times 10^{4}$ mitomycin Ctreated, HIV-infected cells were also main-

tained alone in culture. $-0-$, no toxin; - - day $0-3 ;-\times-$, day $0-7 ;-\triangle-$, day $0-10 ;-\square-$, mitomycin C-treated HIV-infected $\mathrm{H} 9$ cells alone. 


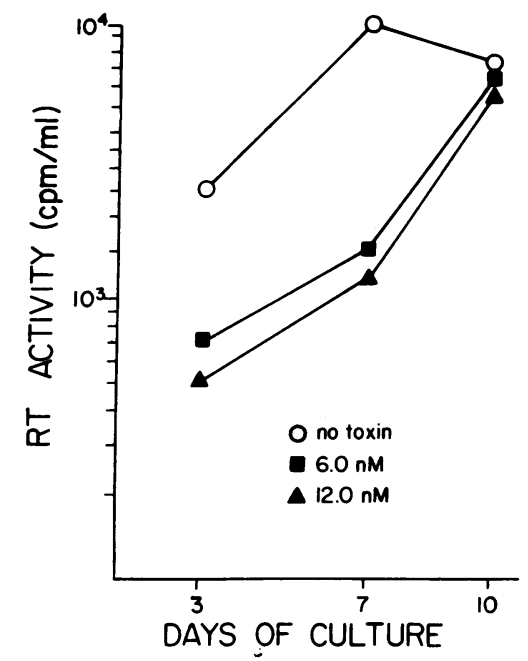

Figure 7. CD4-PE blocks HIV infection of PBLs with HIV, however, only transiently. 1 $\times 10^{6} \mathrm{CD} 8+$ cell-depleted, Con A-activated PBLs were cocultured with $2 \times 10^{4}$ mitomycin C-treated HIV-infected $\mathrm{H}$ 9 cells in the presence of $6.0 \mathrm{nM}$ or $12.0 \mathrm{nM}$ CD4-PE(392) from day 0 to day 7. - o-, no toxin; -,$- 6.0 \mathrm{nM}$ CD4-PE; - $\triangle-, 12.0$ nM CD4-PE.

tained in $12.0 \mathrm{nM}$ as compared to 6.0-nM CD4-PE. The onset of HIV replication was clearly delayed in the cultures treated with $6.0 \mathrm{nM}$ and 12.0-nM CD4-PE, with RT activity only one tenth that of the control cultures on day 7 . However, by day 10 of culture, only $3 \mathrm{~d}$ after removal of CD4-PE, RT activity in supernatants of the CD4-PE-treated cell populations was equal to that of the control cells.

CD4-PE does not inhibit transmission of HIV from infected to uninfected PBLs. Thus, CD4-PE appears to inhibit HIV replication in PBLs, but only transiently. Such a transient inhibition could, however, considerably delay HIV expansion in cell populations susceptible to infection. To assess this possibility, the efficacy of CD4-PE was assessed in another in vitro system. The system chosen for this evaluation was one that should closely approximate the conditions under which a CD4-toxin must work in order to be effective in vivo in the HIV-infected patient. PBLs from an HIV-infected individual were placed in culture with Con A for $4 \mathrm{~d}$. CD8+ cells were then eliminated from these activated PBLs. A similarly prepared CD8 + cell-depleted, Con A-activated PBL population from an uninfected individual was added to these cells and CD4-PE was introduced into these cultured cells. This system, therefore, allowed us to assess the ability of CD4-PE to block transmission of HIV from the rare virus-infected circulating lymphocyte of the individual to other potentially susceptible lymphocytes. Although HIV transmission in this culture system was fully inhibited by an anti-CD4 MAb, neither an inhibition nor a delay in HIV replication was achieved using CD4-PE (Fig. 8).

\section{Discussion}

These studies demonstrate that CD4-PE conjugates inhibit the replication of gp 160-transfected $\mathrm{CHO}$ cells and block replication in virus-infected $\mathrm{H} 9$ cells at nanomolar concentrations. However, this inhibition of virus replication does not appear to be complete since virus replication occurs following removal of the toxin conjugates from these cultures. Moreover, CD4-PE conjugates delay but do not inhibit HIV replication in human PBLs.

The CD4-PE conjugates used in these studies appear to be as potent in their ability to inhibit HIV replication in vitro as those utilized by other investigators. Till et al. demonstrated greater than $90 \%$ inhibition of HIV replication in $\mathrm{H} 9$ cells in the presence of 0.1-nM CD4-ricin (14). Berger et al. demonstrated such an inhibition at a 1-nM concentration, with complete inhibition at a 10-nM concentration of CD4-PE (15). In the present studies, the ID $_{50}$ of the CD4-PE constructs for gp160-transfected CHO cells was $0.0012 \mathrm{nM}$ and complete inhibition of cell replication was observed at a 1.2-nM concentration of CD4-PE. Maximal inhibition of HIV replication in $\mathrm{H} 9$ cells was seen using these conjugates at a 6-nM concentration.

In these studies, we explored the use of CD4-PE conjugates in in vitro systems which should be indicative of the value of such conjugates in a therapeutic setting. In studies of monoclonal antibodies coupled to toxins, it has become apparent that delivery of such conjugates to individuals over a prolonged period of time can result in significant toxin-induced nonspecific tissue injury. Moreover, it is also clear that repeated dosing of such conjugates eventually results in the generation of toxin-specific antibody responses that can neutralize the therapeutic efficacy of these molecules (20). For these reasons it is assumed that toxin conjugates can be used at most intermittently in therapy (20). We therefore assessed viral replication in vitro before and after removing CD4-PE from cultures of HIV-infected $\mathrm{H} 9$ cells. Our observation that viral replication can be demonstrated soon after removal of the CD4-PE-toxin conjugates from these cultured HIV-infected cells is, therefore, troubling.

In further attempts to study the CD4-PE conjugates in physiologically relevant systems, we also assessed the ability of these conjugates to inhibit viral spread from a limited number of HIV-infected PBLs to uninfected PBLs. We were unable to detect CD4-PE inhibition of virus spread from infected to uninfected cells. A number of explanations might be proposed to account for the apparent inefficiency of CD4-PE to inhibit HIV spread and replication under these in vitro conditions.

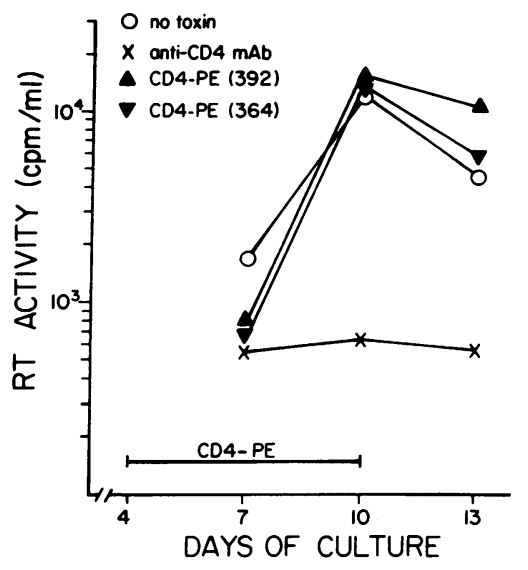

Figure 8. CD4-PE does not block transmission of HIV from infected to uninfected cells in PBLs of an HIV-infected individual. PBLs obtained from an HIV-infected individual were activated with Con $\mathrm{A}$ for 4 d. $\mathrm{CD} 8+$ cells were then removed by a panning procedure. $1 \times 10^{6}$ similarly treated CD8+ cell-depleted PBLs derived from a healthy individual were cocultured with $1 \times 10^{5}$ of

the cells from the HIV-infected individual in the presence of $6.0-\mathrm{nM}$ CD4-PE(392), 6.0-nM CD4-PE(364), or a 1:400 dilution of monoclonal anti-CD4 antibody ascites (19Thy5D7), an antibody that blocks binding of HIV to CD4. The CD4-PE or antibody were present in the culture from day 4 to day 10 . Coculture with cells of the normal individual began on day 4 of culture. $-0-$, no toxin; $-\times$ - anti-CD4 mAb (19Thy5D7); — —, CD4-PE(392); $-\nabla-$, CD4-PE(364). 
HIV may spread from cell to cell in lymphocyte populations before envelope glycoprotein is expressed on the surface of these cells in quantities sufficient to make the cells optimal targets for CD4-toxin conjugates. If this, in fact, occurs, the use of the CD4 toxins to inhibit spread of virus in PBLs may be of limited value. CD4 expression is also considerably greater on PBLs than on H9 cells. PBLs may, therefore, be more susceptible to infection by limited numbers of HIV particles than are $\mathrm{H} 9$ cells. If this were true, CD4-PE might be less efficient at blocking HIV infection in PBLs than in H9 cells.

The experiments described in these studies do not contradict findings reported by other investigators working with CD4-PE. Chaudhary et al. did not measure HIV replication in CD4-PE-treated cells. They only assessed the proliferative capacity of CV-1 cells infected with vaccinia-gp 160 and HIV-infected A3.01 cells after a brief exposure to CD4-PE (13). Till et al. similarly only measured the proliferative activity of CD4PE-treated HIV-infected H9 cells (14). Although Berger et al. did demonstrate a CD4-PE-induced inhibition of RT generation by HIV-infected cells in vitro, they studied virus replication only in A3.01 cells (15). These experiments assessed CD4-PE-mediated inhibition of HIV replication in $\mathrm{H} 9$ cells and, more importantly, in human PBLs. Moreover, in the experiments most central to these studies, CD4-PE was assessed for its ability to block transmission of HIV from infected to uninfected PBLs. The kinetics of HIV replication in H9 cells and lectin-activated human PBLs, and the susceptibility of these virus-infected cells to killing by CD4-PE, might be expected to differ substantially from those of HIV-infected A3.01 cells.

While these studies suggest that CD4-PE may not completely eliminate replicating virus from an infected cell population, CD4-toxin conjugates may still prove of value in the therapeutic armamentarium against AIDS. CD4 conjugates prepared with cell toxins more potent than PE may be more efficient at eliminating virus-infected cells than CD4-PE. CD4-toxin conjugates may also prove more toxic in vivo than in vitro. Those issues notwithstanding, the data in the present study clearly demonstrate that CD4-PE does delay the spread of HIV in culture. It is, therefore, possible that such a conjugate may prove a useful adjunct to other modalities of treatment in AIDS.

\section{Acknowledgments}

We thank M. Hirsch for providing blood samples from HIV-1 infected patients, and D. Brosseau for preparing this manuscript.

This work was supported by National Institutes of Health grants AI-20729, CA-50139, and RR-00168, and funds from Biogen, Inc. Dr. Letvin is a recipient of an American Cancer Society Faculty Research Award.

\section{References}

1. McDougal, J. S., M. S. Kennedy, J. M. Sligh, S. P. Cort, A. Mawle, and J. K. A. Nicholson. 1986. Binding of HTLV-III/LAV to $\mathrm{T} 4+\mathrm{T}$ cells by a complex of the $110 \mathrm{~K}$ viral protein and the T4 molecule. Science (Wash. DC). 231:382-385.
2. Dalgleish, A. G., P. C. L. Beverley, P. R. Clapham, D. H. Crawford, M. F. Greaves, and R. A. Weiss. 1984. The CD4 (T4) antigen is an essential component of the receptor for the AIDS retrovirus. Nature (Lond.). 312:763-767.

3. Klatzmann, D., E. Champagne, S. Chamaret, J. Gruest, D. Guetard, T. Hercend, J. C. Gluckman, and L. Montagnier. 1984. T lymphocyte $\mathrm{T} 4$ molecule behaves as the receptor for human retrovirus LAV. Nature (Lond.). 312:767-768.

4. Maddon, P. J., A. G. Dalgleish, J. S. McDougal, P. R. Clapham, R. A. Weiss, and R. Axel. 1986. The T4 gene encodes the AIDS virus receptor and is expressed in the immune system and the brain. Cell. 47:333-348.

5. Fisher, R. A., J. M. Bertonis, W. Meier, V. A. Johnson, D. S. Costopoulos, T. Liu, R. Tizard, B. D. Walker, M. S. Hirsch, R. T. Schooley, and R. A. Flavell. 1988. HIV infection is blocked in vitro by recombinant soluble CD4. Nature (Lond.). 331:76-78.

6. Hussey, R. E., N. E. Richardson, M. Kowalski, N. R. Brown, H.-C. Chang, R. F. Siliciano, T. Dorfman, B. Walker, J. Sodroski, and E. L. Reinherz. 1988. A soluble CD4 protein selęctivity inhibits HIV replication and syncytium formation. Nature (Lond.). 331:78-81.

7. Deen, K. C., J. S. McDougal, R. Inacker, G. Folena-Wasserman, J. Arthos, J. Rosenberg, P. J. Maddon, R. Axel, and R. W. Sweet. 1988. A soluble form of CD4 (T4) protein inhibits AIDS virus infection. Nature (Lond.). 331:82-84.

8. Traunecker, A., W. Luke, and K. Karjalainen. 1988. Soluble CD4 molecules neutralize human immunodeficiency virus type I. $\mathrm{Na}$ ture (Lond.). 331:84-86.

9. Smith, D. H., R. A. Byrn, S. A. Marsters, T. Gregory, J. E. Groopman, and D. J. Capon. Blocking of HIV-1 infectivity by a soluble, secreted form of the CD4 antigen. Science (Wash. DC). 238:1704-1707.

10. Watanabe, M., K. A. Reimann, P. A. DeLong, T. Liu, R. A. Fisher, and N. L. Letvin. 1989. Effect of recombinant soluble CD4 in rhesus monkeys infected with simian immunodeficiency virus of macaques. Nature (Lond.). 337:267-270.

11. Schooley, R. T., T. C. Merigan, P. Gaut, M. S. Hirsch, M. Holodniy, T. Flynn, S. Liu, R. E. Byington, S. Henochowicz, E. Gubish, et al. 1990. Recombinant soluble CD4 therapy in patients with acquired immunodeficiency syndrome (AIDS) or AIDS-related complex. A phase I-II escalating dosage trial. Ann. Intern. Med. 112:247253.

12. Kahn, J. O., J. D. Allan, T. L. Hodges, L. D. Kaplan, C. J. Arri, H. F. Fitch, A. E. Izu, J. Mordenti, S. A. Sherwin, J. E. Groopman, and P. A. Volberding. 1990 . The safety and pharmacokinetics of recombinant soluble CD4 ( $\mathrm{rCD} 4)$ in subjects with the acquired immunodeficiency syndrome (AIDS) and AIDS-related complex. Ann. Intern. Med. 112:254-261.

13. Chaudhary, V. K., T. Mizukami, T. R. Fuerst, D. J. FitzGerald, B. Moss, I. Pastan, and E. A. Berger. 1988. Selective killing of HIV-infected cells by recombinant human CD4-pseudomonas exotoxin hybrid protein. Nature (Lond.). 335:369-372.

14. Till, M. A., V. Ghetie, T. Gregory, E. J. Patzer, J. P. Porter, J. W. Uhr, D. J. Capon, and E. S. Vitetta. 1988. HIV-infected cells are killed by rCD4-ricin A chain. Science (Wash. DC). 242:1166-1168.

15. Berger, E. A., K. A. Clouse, V. K. Chaudhary, S. Chakrabarti, D. J. FitzGerald, I. Pastan, and B. Moss. 1989. CD4-Pseudomonas exotoxin hybrid protein blocks the spread of human immunodeficiency virus infection in vitro and is active against cells expressing the envelope glycoproteins from diverse primate immunodeficiency retroviruses. Proc. Natl. Acad. Sci. USA. 86:9539-9543.

16. Pastan, I., and D. FitzGerald. 1989. Pseudomonas exotoxin: chimeric toxins. J. Biol. Chem. 264:15157-15160.

16a. Maddon, P. J., D. R. Littman, M. Godfrey, D. E. Maddon, L. Chess, and R. Axel. 1985. The isolation and nucleotide sequence of a cDNA encoding the $T$ cell surface protein T4: a new member of the immunoglobulin gene family. Cell. 42:93-104. 
16b. Littman, D. R., P. J. Maddon, and R. Axel. 1988. Corrected CD4 sequence. Cell. 55:541.

16c. Gray, G. L., D. H. Smith, J. S. Baldridge, R. N. Harkins, M. L. Vasil, E. Y. Chen, and H. L. Heyneker. 1984. Cloning, nucleotide sequence, and expression in Escherichia coli of the exotoxin A structural gene of Pseudomonas aeruginosa. Proc. Natl. Acad. Sci. USA. 81:2645-2649.

16d. Hwang, J., D. J. FitzGerald, S. Adhya, and I. Pastan. 1987. Functional domains of Pseudomonas exotoxin identified by deletion analysis of the gene expressed in E. coli. Cell. 48:129-136.

17. Wysocki, L. J., and V. L. Sato. 1978. "Panning" for lymphocytes: a method for cell selection. Proc. Natl. Acad. Sci. USA. 75:2844-2848.
18. Kannagi, M., L. V. Chalifoux, C. I. Lord, and N. L. Letvin. 1988. Suppression of simian immunodeficiency virus replication in vitro by CD8+ lymphocytes. J. Immunol. 140:2237-2242.

19. Daniel, M. D., N. L. Letvin, N. W. King, M. Kannagi, P. K. Sehgal, R. D. Hunt, P. J. Kanki, M. Essex, and R. C. Desrosiers. 1985. Isolation of T-cell tropic HTLV-III-like retrovirus from macaques. Science (Wash. DC). 228:1201-1204.

20. Reimann, K. A., J. M. Lambert, R. L. Kirkman, S. H. Turner, S. F. Schlossman, and N. L. Letvin. 1989. In vivo administration of lymphocyte-specific monoclonal antibodies in nonhuman primates. V. Immune response to murine monoclonal antibodies and immunotoxins abrogates their cytotoxic activity. Transplantation (Baltimore). 48:906-912. 